\title{
Ractopamine in diets for finishing pigs of different sexual categories ${ }^{1}$
}

\section{Carlos Enrique da Trindade Barbosa ${ }^{2}$, Carolina Teixeira Costa Silva ${ }^{2}$, Vinícius de Souza Cantarelli ${ }^{2}$, Márcio Gilberto Zangeronimo ${ }^{3}$, Raimundo Vicente de Sousa ${ }^{3}$, Cesar Augusto Pospissil Garbossa ${ }^{2}$, Níkolas de Oliveira Amaral ${ }^{4}$, Walmes Marques Zeviani ${ }^{5}$}

\footnotetext{
1 Financed by CNPq with support of Fapemig and INCT-CA.

2 Departamento de Zootecnia - UFLA.

${ }^{3}$ Departamento de Medicina Veterinária - UFLA.

${ }^{4}$ Escola Agrotécnica Federal de Machado - Machado, MG.

${ }^{5}$ Departamento de Estatística - UFPR.
}

\begin{abstract}
Performance and carcass and cut yield of finishing pigs of three sexual categories fed diets with different levels of ractopamine were studied. Forty-eight hybrid animals (initial weight of $92.1 \pm 2.4 \mathrm{~kg}$ ) were distributed in a completely randomised design in $3 \times 2$ factorial arrangement (three sexual categories: surgically castrated males, two females and immunologically castrated males - with or without $10 \mathrm{ppm}$ of ractopamine), totalling six treatments and eight repetitions with one animal per experimental plot during 28 days. Ractopamine improved weight gain and feed conversion of all sexual categories. The best results were obtained with immunologically castrated males, which, in turn, had lower carcass yield and backfat thickness in the belly. In the absence of ractopamine, depth and loin eye area were higher in females but no differences in these variables were observed between categories when this additive was used. Ractopamine increased the sirloin yield in all sexual categories. There was no difference in bonus index. Ractopamine improves the performance of pigs of 92 to $125 \mathrm{~kg}$. Immunologically castrated males have the best performance responses to ractopamine, but with losses in carcass yield, loin characteristics and backfat thickness of the belly.
\end{abstract}

Key Words: additives, bonus rate, carcass modifier, immunologically castrated males, swine nutrition

\section{Introduction}

In recent decades there has been a growing demand for animal protein in the world, encouraging the production in countries with potential for expansion. To increase the supply of pork, alternatives in pig production have been used to improve performance and slaughter weight of animals. However, in the finishing phase, animals reduce the daily gain of muscle tissue and deposit more fat in the carcass as a result of increased final weight. The higher fat in the carcass decreases the quality of the cuts (Latore et al., 2004).

Another important aspect in the production system is the emergence of a new sexual category, the immunologically castrated males. This technique involves the application of immunogenic factors that stimulate the production of antibodies to the hypothalamic gonadotropin-releasing hormone $(\mathrm{GnRH})$, reducing the production of steroids involved with reproductive characteristics and consequently the production of undesirable odour in the carcass (Jaros et al., 2005). The advantage of the immunocastration technique is the integrity of piglets that were surgically castrated in early life.
Ractopamine is a nutrient divisor that improves the performance and carcass characteristics of finishing pigs, with effects on the endocrine system and metabolism of proteins, lipids and carbohydrates (Dunshea et al., 2009). The effects of this addictive on the performance and carcass characteristics of females and surgically castrated males are well-known, and more pronounced in females, besides being more economically feasible (Amaral et al., 2009). Results in the literature suggest that similar results can be obtained with immunologically castrated males (RikardBell et al., 2009) but few studies comparing the responses in different sexual categories have been conducted.

Thus, this study was conducted to evaluate the performance, carcass and cut yield and the bonus rate of females and surgically or immunologically castrated males in finishing phase fed diets with or without ractopamine.

\section{Material and Methods}

The experiment was conducted in the Centro Experimental de Suínos of the Departamento de Zootecnia of Universidade Federal de Lavras. 
Forty-eight commercial hybrid pigs were used - sixteen of each sexual category (female and surgically and immunologically castrated males), with initial weight of $92.1 \pm 2.4 \mathrm{~kg}$ and final weight of $125.0 \pm 4.9 \mathrm{~kg}$. Animals were individually housed in stalls $\left(12 \mathrm{~m}^{2} /\right.$ animal) during 28 days. The temperature was monitored by three maximum and minimum thermometers placed at different locations in the shed.

The experimental design was completely randomised in a $3 \times 2$ factorial arrangement (three sexual categories females and surgically and immunologically castrated males - and two diets, with or without $10 \mathrm{ppm}$ of ractopamine), totalling six treatments with eight repetitions of one animal each.

The immunocastration consisted of two subcutaneous applications of $2.0 \mathrm{~mL}$ of vaccine Vivax ${ }^{\circledR}$ (Pfizer Animal Health) in the cervical region of the animals. The first application was made when animals were 109 days of age and the second at 137 days, when the experiment began.

Diets were based on corn and soybean meal, supplemented with vitamins, minerals and amino acids to meet the minimum requirements suggested for the genetic line utilized (Toppigs C40 x Tempo), with the exception of lysine, which increased by $30 \%$ due to the use of ractopamine
(Mitchell et al., 1990; Table 1). Ractopamine was added to replace the kaolin.

The animals were weighed at the beginning and end of the experiment for evaluation of weight gain. Diets were ad libitum and leftovers were weighed daily to determine the feed intake. Feed conversion was determined by the feed:gain ratio.

At the end of the experiment, the animals were subjected to fasting for 12 hours, weighed and slaughtered using electrical desensitising. After slaughter, the viscera were removed and carcasses were sawn in half lengthwise and weighed. The left half carcass of each pig was cooled at $4.0^{\circ} \mathrm{C}$ for 24 hours. Backfat thickness, depth of loin and loin eye area were measured in accordance with the Brazilian Method of Carcass Evaluation (ABCS, 1973).

The carcass meat yield and the bonus index were estimated by equations described by Guidoni (2000):

$\mathrm{CMY}=65.92-(0.685 * \mathrm{BT})+(0.094 * \mathrm{LD})-(0.026 * \mathrm{HCW})$ where $\mathrm{CMY}=$ carcass meat yield $(\%), \mathrm{BT}=$ backfat thickness $(\mathrm{mm}), \mathrm{LD}=$ loin depth $(\mathrm{mm})$ and $\mathrm{HCW}=$ hot carcass weight.

$\mathrm{BI}=23.6+0.286 * \mathrm{PCARQ}+\mathrm{PCMF}$

where $\mathrm{BI}=$ bonus index $(\%)$ and $\mathrm{PCMF}=$ percentage of meat estimated in chilled carcass.

Table 1 - Centesimal and calculated composition of experimental diets ${ }^{1}$

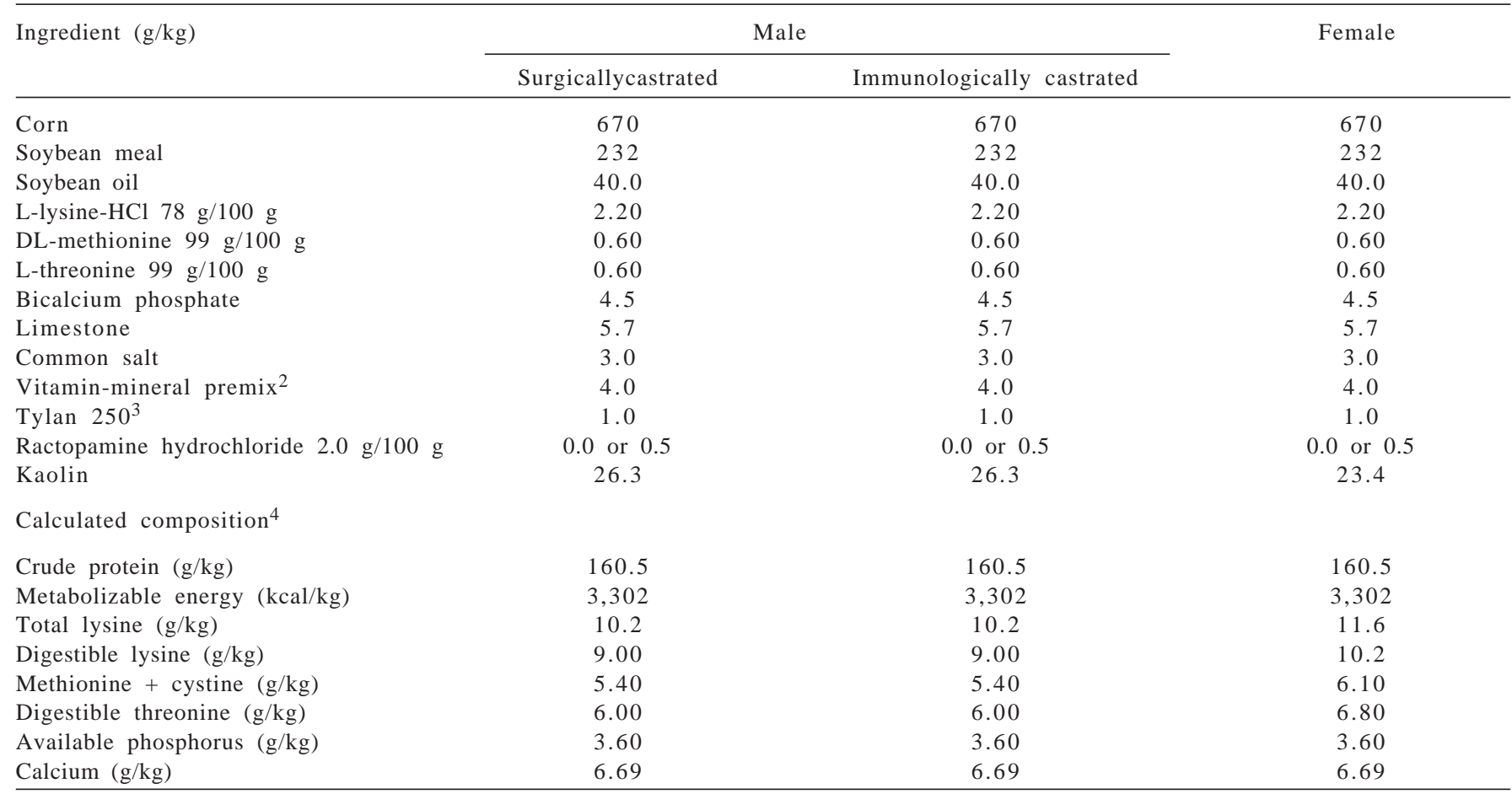

1 Based on the requirements table for Toppigs genetic.

${ }^{2}$ Composition per kg of product: calcium - 98,800 mg; cobalt - 185 mg; copper - 15.75 mg; iron - 26,250 mg; iodine - 1,470 mg; manganese - 41,850 mg; zinc - 77,999 mg; folic acid - 116,55 mg; pantothenic acid - 2,334 mg; biotin - $5.28 \mathrm{mg}$; niacin - 5,600 mg; pyridoxine - $175 \mathrm{mg}$; riblavin - $933 \mathrm{mg}$; thiamine - $175 \mathrm{mg}$; vitamin A - 1,225,000 UI; vitamin D3 - 315,000 UI; vitamin E - 1,400 mg; vitamin K3 - 700 mg; vitamin B12 - 6.83 mg; selenium - 105 mg; and antioxidant - 1,500 mg .

3 Antibiotic with tylosin $25 \%$.

${ }^{4}$ Composition values based on Rostagno et al. (2005). 
Ham, shoulder blade and sirloin yield, backfat thickness of the belly and belly flexibility were evaluated. The belly flexibility was measured following an adapted method proposed by Rentfrowa et al. (2003).

The data were subjected to covariance analysis after the error normality test. The initial weight and age of the animals were used as covariates. The deployment of interaction was considered when $\mathrm{P}<0.10$. The averages obtained with the different sexual categories were compared by the Tukey test at 0.05 and the averages obtained with diets with or without ractopamine were compared by the F test. All statistical analyses were performed using the statistical software SAS (Statistical Analysis System, 1996).

\section{Results and Discussion}

The average temperature of the shed during the 28 days of the experiment was $18.42 \pm 2.78^{\circ} \mathrm{C}$. In the first 14 days of the experiment, the daily feed intake was not affected $(\mathrm{P}>0.05)$ by ractopamine or by sexual category of animals (Table 2 ), but the ractopamine improved $(\mathrm{P}<0.05)$ the daily weight gain in $13 \%$ of animals in the three sexual categories.

The sexual category did not influence $(\mathrm{P}>0.05)$ the feed conversion of the animals. However, effect $(\mathrm{P}<0.05)$ of ractopamine was observed only on surgically castrated males. In these animals, an improvement of $17 \%$ was observed. In the other sexual categories, ractopamine did not affect feed conversion at 14 days of use. Considering the results obtained with immunologically castrated males, Rikard-Bell et al. (2009) observed a positive effect of this additive in feed conversion as early as after 14 days of use, maintaining this result at 31 days. It is important to observe that these authors worked with animals which were lighter (72 kg) compared with those of the present study (92 kg).

Considering the whole period, the daily feed intake of animals did not differ $(\mathrm{P}>0.05)$ with inclusion of ractopamine in feed or the sexual category. Contrarily, Rikard-Bell et al. (2009) and Moraes et al. (2010) observed higher values in immunologically castrated males compared with females.

The daily weight gain of animals improved $(\mathrm{P}<0.05)$ with the ractopamine inclusion in the diet. An improvement of $7 \%$ was observed, compared with diets without supplementation. Regarding sexual category, the best results $(\mathrm{P}<0.05)$ were observed in immunologically castrated males. With or without ractopamine, this category showed weight gain superior by $13 \%$ compared with females and surgically castrated males. Comparing sexual categories, Rikard-Bell et al. (2009) observed higher weight gain in immunologically castrated males when compared with females. However, the authors did not use a specific diet for females, which may have limited the development of this sexual category, compared with others.

In the absence of ractopamine, Moraes et al. (2010) also observed that immunologically castrated males had higher

Table 2 - Performance of swine of different sexual categories feed diets supplemented with and without ractopamine

\begin{tabular}{|c|c|c|c|c|c|c|c|c|}
\hline \multirow[t]{2}{*}{ Variable } & \multirow[t]{2}{*}{ RAC (ppm) } & \multicolumn{3}{|c|}{ Sexual category } & \multirow[t]{2}{*}{ Mean } & \multicolumn{3}{|c|}{ Significance } \\
\hline & & SCM & ICM & FE & & RAC & SC & $\mathrm{RAC} \times \mathrm{SC}$ \\
\hline & & & & & - 1 to 14 days - & & & \\
\hline \multirow[t]{3}{*}{ Average weight gain (kg/day) } & 0 & 1.11 & 1.27 & 1.25 & $1.21 \mathrm{~b}$ & 0.0084 & 0.1222 & 0.5422 \\
\hline & 10 & 1.31 & 1.48 & 1.32 & $1.37 \mathrm{a}$ & & & \\
\hline & Mean & 1.21 & 1.37 & 1.29 & & & & \\
\hline \multirow[t]{3}{*}{ Average feed intake (kg/day) } & 0 & 3.70 & 3.39 & 3.39 & 3.49 & 0.7065 & 0.2095 & 0.7305 \\
\hline & 10 & 3.62 & 3.51 & 3.47 & 3.53 & & & \\
\hline & Mean & 3.66 & 3.45 & 3.43 & & & & \\
\hline \multirow[t]{4}{*}{ Feed conversion } & 0 & $3.33 \mathrm{Bb}$ & $2.67 \mathrm{~A}$ & $2.71 \mathrm{~A}$ & 2.90 & $<0.001$ & 0.1005 & 0.0082 \\
\hline & 10 & $2.76 \mathrm{a}$ & 2.37 & 2.63 & 2.59 & & & \\
\hline & Mean & 3.05 & 2.52 & 2.67 & & & & \\
\hline & & & & & - 1 to 28 days - & & & \\
\hline \multirow[t]{3}{*}{ Average weight gain (kg/day) } & 0 & 1.10 & 1.26 & 1.06 & $1.14 \mathrm{~b}$ & 0.0249 & 0.0010 & 0.4320 \\
\hline & 10 & 1.15 & 1.30 & 1.20 & $1.22 \mathrm{a}$ & & & \\
\hline & Mean & $1.13 \mathrm{~B}$ & $1.28 \mathrm{~A}$ & $1.13 \mathrm{~B}$ & & & & \\
\hline \multirow[t]{3}{*}{ Average feed intake (kg/day) } & 0 & 3.74 & 3.77 & 3.48 & 3.67 & 0.6479 & 0.4775 & 0.2122 \\
\hline & 10 & 3.70 & 3.67 & 3.73 & 3.70 & & & \\
\hline & Mean & 3.72 & 3.72 & 3.61 & & & & \\
\hline \multirow[t]{3}{*}{ Feed conversion } & 0 & 3.40 & 2.99 & 3.28 & $3.23 b$ & 0.0004 & $<0.0001$ & 0.8599 \\
\hline & 10 & 3.22 & 2.82 & 3.11 & $3.05 a$ & & & \\
\hline & Mean & $3.31 \mathrm{~A}$ & $2.91 \mathrm{~B}$ & $3.20 \mathrm{~A}$ & & & & \\
\hline
\end{tabular}


weight gain, compared with females or surgically castrated males, but this response was reversed with the use of the supplement. According to the authors, a possible explanation for this result may be the nutritional requirements of the different categories assessed, suggesting that immunologically castrated males have amino acid requirements similar to non-castrated males and superior to other sexual categories (Xue et al., 1997).

Ractopamine improved $(\mathrm{P}<0.05)$ the feed conversion by $5.6 \%$ in all sexual categories and immunocastration by $12 \%$ compared with surgically castrated males and $9 \%$ compared with females. Several studies in the literature show the benefits of ractopamine in finishing pigs (Cantarelli et al., 2009a; Almeida et al., 2010). The results obtained with this additive confirm its efficiency in improving the animal performance, regardless of sexual category. In this study, the increase in weight gain was already around $13 \%$ in the first period (14 days) and 7\% in the total period (28 days). This result may be related to greater stimulus for the muscle tissue synthesis in the animals (Aalhus et al., 1992). The lack of influence of this additive in feed intake associated with high weight gain also justifies the best feed conversion in others studies (Amaral et al., 2009; Ferreira et al., 2011).

With the exception of variables depth loin and loin eye area, there was no effect of ractopamine $(\mathrm{P}>0.05)$ on the carcass characteristics evaluated (Table 3). These results are different from those found by Armstrong et al. (2004) and Amaral et al. (2009). These authors found significant improvement of quantitative characteristics of carcasses, mainly with regard to increasing of the meat percentage.
According to Schinckel et al. (2003), ractopamine reduces the synthesis of fatty acids in adipose tissue and increases the protein synthesis, resulting in improving the meat percentage in the carcasses.

Considering the sexual categories, immunologically castrated males showed $(\mathrm{P}<0.05)$ lower carcass yield, but similar $(\mathrm{P}>0.05)$ backfat thickness and carcass meat yield to other categories. Moraes et al. (2010) observed that immunologically castrated males also had lower carcass yield compared with females, but higher compared with surgically castrated males. On the other hand, Gispert et al. (2010) reported lower carcass yield in immunologically castrated males compared with surgically castrated ones.

In contrast to the results of the present study, Gispert et al. (2010) observed greater backfat thickness in surgically and immunologically castrated males compared with females and non-castrated males. Rikard-Bell et al. (2009) also observed higher backfat thickness in immunologically castrated males compared with females and non-castrated males. Based on these results, and as also found by Dunshea et al. (2001), it is supposed that the backfat thickness is greater in immunologically castrated males compared with females and non-castrated males, but similar to surgically castrated animals. However, this cannot be observed in this study, probably due to the weight range studied, which was higher compared with most studies in the literature with immunologically castrated animals. At later ages, the animals have a tendency to deposit more body fat, making it difficult to observe statistical differences in backfat thickness.

Table 3 - Carcass characteristics of swine of different sexual categories fed diets with and without ractopamine supplementation

\begin{tabular}{|c|c|c|c|c|c|c|c|c|}
\hline \multirow[t]{2}{*}{ Variable } & \multirow[t]{2}{*}{ RAC (ppm) } & \multicolumn{3}{|c|}{ Sexual category } & \multirow[t]{2}{*}{ Mean } & \multicolumn{3}{|c|}{ Significance } \\
\hline & & SCM & ICM & $\mathrm{FE}$ & & RAC & SCM & ICM \\
\hline \multirow[t]{3}{*}{ Carcass yield (\%) } & 0 & 82.97 & 80.74 & 82.93 & 82.21 & 0.6055 & $<0.0001$ & 0.5154 \\
\hline & 10 & 82.86 & 81.44 & 82.86 & 82.38 & & & \\
\hline & Mean & $82.91 \mathrm{~A}$ & $81.08 B$ & $82.89 \mathrm{~A}$ & & & & \\
\hline \multirow[t]{3}{*}{ Backfat thickness (mm) } & 0 & 19.75 & 17.43 & 17.56 & 18.25 & 0.8588 & 0.2483 & 0.7483 \\
\hline & 10 & 18.98 & 17.87 & 18.32 & 18.39 & & & \\
\hline & Mean & 19.36 & 17.65 & 17.93 & & & & \\
\hline \multirow[t]{3}{*}{ Loin depth (mm) } & 0 & $66.06 \mathrm{AB}$ & $60.68 \mathrm{Bb}$ & $67.60 \mathrm{~A}$ & 64.80 & 0.0023 & 0.2528 & 0.0252 \\
\hline & 10 & 68.68 & $70.35 a$ & 68.59 & 69.00 & & & \\
\hline & Mean & 67.37 & 65.51 & 68.10 & & & & \\
\hline \multirow[t]{3}{*}{ Loin eye area $\left(\mathrm{cm}^{2}\right)$} & 0 & $34.40 \mathrm{AB}$ & $31.17 \mathrm{Bb}$ & $36.20 \mathrm{~A}$ & 33.90 & 0.0009 & 0.0039 & 0.0369 \\
\hline & 10 & 35.14 & $36.83 a$ & 38.24 & 36.74 & & & \\
\hline & Mean & 34.77 & 34.00 & 37.22 & & & & \\
\hline \multirow[t]{3}{*}{ Meat yield (\%) } & 0 & 56.27 & 57.03 & 57.04 & 56.78 & 0.167 & 0.1745 & 0.5294 \\
\hline & 10 & 56.83 & 58.84 & 57.27 & 57.65 & & & \\
\hline & Mean & 56.55 & 57.93 & 57.16 & & & & \\
\hline \multirow[t]{3}{*}{ Bonus index (\%) } & 0 & 109.40 & 110.50 & 109.80 & 109.90 & 0.4574 & 0.1309 & 0.8073 \\
\hline & 10 & 109.50 & 111.60 & 110.00 & 110.38 & & & \\
\hline & Mean & 109.47 & 111.02 & 109.93 & & & & \\
\hline
\end{tabular}

SCM - surgically castrated male; ICM - immunologically castrated male; FE - female; SC - sexual category; RAC - ractopamine.

Means followed by different lowercase letters in column and uppercase letters in the row differ $(\mathrm{P}<0.05)$ by $\mathrm{F}$ test and Tukey test, respectively. 
With regard to the meat carcass percentage, in contrast to the present study, Moraes et al. (2010) observed that immunologically castrated males were very similar to females, but higher if compared with surgically castrated ones. This can probably be related to the weight range studied.

There was no effect $(\mathrm{P}>0.05)$ of sexual category or ractopamine on the meat carcass percentage. This result was similar to those found by Pena et al. (2008) using ractopamine and Moraes et al. (2010) using ractopamine in females and surgically and immunologically castrated males.

Some studies have also shown higher bonus rates using ractopamine in finishing pigs (Cantarelli et al. 2009b; Amaral et al., 2009), but in the present study, the results obtained with the carcass characteristics did not allow observation of any significant differences in this variable.

Interaction between ractopamine and sexual category was observed $(\mathrm{P}<0.05)$ only in loin depth and loin eye area. In the absence of ractopamine, immunologically castrated males had $(\mathrm{P}<0.05)$ less loin depth and loin eye area. However, in the presence of this additive, the values were similar $(\mathrm{P}>0.05)$ between the categories. Ractopamine improved $(\mathrm{P}<0.05)$ the muscle mass in the loin by $17 \%$ only in immunologically castrated males. This result shows a better response of this sexual category to ractopamine, suggesting that these animals still have great potential for muscle tissue deposition compared with others. Amaral et al. (2009), Almeida et al. (2010) and Ferreira et al. (2011), working with females and surgically castrated males, also found a positive effect of ractopamine on this variable.

With respect to cut yield, ractopamine influenced $(\mathrm{P}<0.05)$ only sirloin yield, which was improved by about 7\% (Table 4). Similar results were observed by Cantarelli et al. (2008) and Amaral et al. (2009), using ractopamine in finishing pigs. As for ham yield, Cantarelli et al. (2008) and Ferreira et al. (2011) also found no effect of ractopamine on this variable.

As for belly quality, the lower backfat thickness observed in the belly of immunologically castrated males was not sufficient $(\mathrm{P}>0.05)$ to change belly yield or belly flexibility. Cantarelli et al. (2008) and Ferreira et al. (2011) also found no effect of ractopamine on belly yield.

Divergent results with ractopamine are found in the literature with regard to the cut yields in pigs (Uttaro et al., 1993, Marinho et al., 2007a, b). These results may be more related to the genes whose lineages have a different potential response in the cut yields, regardless of the presence or absence of ractopamine in the diets.

Cantarelli et al. (2008), Almeida et al. (2010) and Ferreira et al. (2011) found no effect of ractopamine on the belly flexibility. On the other hand, Carr et al. (2005) observed greater belly flexibility in animals fed diets with $10 \mathrm{ppm}$ of ractopamine. Amaral et al. (2009) also found lower belly flexibility in surgically castrated males compared with females. These differences may be due to the meat:fat ratio of the belly, where the ractopamine can act in differentiated ways, depending on the genes, weight and age of the animals. According to Ji et al. (2006), higher values of fat normally found in females may be associated with the

Table 4 - Cut yields and belly quality of swine of different sexual categories feed diets supplemented with and without ractopamine

\begin{tabular}{|c|c|c|c|c|c|c|c|c|}
\hline \multirow[t]{2}{*}{ Variable } & \multirow[t]{2}{*}{ RAC (ppm) } & \multicolumn{3}{|c|}{ Sexual category } & \multirow[t]{2}{*}{ Mean } & \multicolumn{3}{|c|}{ Significance } \\
\hline & & SCM & ICM & $\mathrm{FE}$ & & RAC & SCM & ICM \\
\hline \multirow[t]{3}{*}{ Ham yield (\%) } & 0 & 27.44 & 26.90 & 27.94 & 27.42 & 0.8371 & 0.4657 & 0.2641 \\
\hline & 10 & 27.04 & 27.60 & 27.44 & 27.36 & & & \\
\hline & Mean & 27.24 & 27.25 & 27.69 & & & & \\
\hline \multirow[t]{3}{*}{ Blade shoulder yield (\%) } & 0 & 19.15 & 18.72 & 19.04 & 18.97 & 0.6621 & 0.9535 & 0.5251 \\
\hline & 10 & 18.80 & 19.42 & 19.18 & 19.13 & & & \\
\hline & Mean & 18.98 & 19.07 & 19.11 & & & & \\
\hline \multirow[t]{3}{*}{ Sirloin yield (\%) } & 0 & 0.73 & 0.74 & 0.70 & $0.72 b$ & 0.0188 & 0.3769 & 0.6730 \\
\hline & 10 & 0.75 & 0.80 & 0.77 & $0.77 a$ & & & \\
\hline & Mean & 0.74 & 0.77 & 0.74 & & & & \\
\hline \multirow[t]{3}{*}{ Belly yield (\%) } & 0 & 6.25 & 6.34 & 6.80 & 6.46 & 0.7518 & 0.2089 & 0.7845 \\
\hline & 10 & 6.47 & 6.42 & 6.69 & 6.53 & & & \\
\hline & Mean & 6.36 & 6.38 & 6.75 & & & & \\
\hline \multirow[t]{3}{*}{ Backfat thickness of belly (mm) } & 0 & 16.37 & 12.64 & 21.54 & 16.85 & 0.9487 & $<0.0001$ & 0.6310 \\
\hline & 10 & 16.21 & 11.83 & 22.55 & 16.86 & & & \\
\hline & Mean & $16.26 \mathrm{~B}$ & $12.23 \mathrm{C}$ & $22.05 \mathrm{~A}$ & & & & \\
\hline \multirow[t]{3}{*}{ Belly flexibility (cm) } & 0 & 15.15 & 14.64 & 15.47 & 15.09 & 0.1150 & 0.0544 & 0.3554 \\
\hline & 10 & 15.43 & 14.97 & 17.50 & 15.97 & & & \\
\hline & Mean & 15.29 & 14.80 & 16.48 & & & & \\
\hline
\end{tabular}

SCM - surgically castrated male; ICM - immunologically castrated male; FE - female; SC - sexual category; RAC - ractopamine.

Means followed by different lowercase letters in column and uppercase letters in the row differ by $\mathrm{F}$ test and by Tukey test, respectively ( $<<0.05$ ). 
higher concentration of adipocytes in the mammary gland.

The sexual category influenced $(\mathrm{P}<0.05)$ only backfat thickness of the belly. Immunologically castrated males had the lowest value, followed by surgically castrated and females. This reduction in belly fat was $25 \%$ when compared with the surgically castrated males and $45 \%$ when compared with females.

See et al. (2004) and Almeida et al. (2010) also found no effect of sexual category on sirloin yield. However, Gispert et al. (2010) observed lower sirloin yield in surgically castrated males compared with females, non-castrated males and immunologically castrated males. This increase in sirloin yield can be related to the effect of nutrient distribution of ractopamine, directing more nutrients to protein synthesis in this specific muscle.

No interaction $(\mathrm{P}>0.05)$ was observed in the variables analyzed. Evaluating the belly yield, Almeida et al. (2010) observed that the ractopamine acted more in surgically castrated males that had higher yields than females. Gispert et al. (2010) also observed higher belly yield in immunologically and surgically castrated males compared with the non-castrated ones. These authors also observed that females showed intermediate results between the sexual categories studied.

\section{Conclusions}

Ractopamine increases weight gain in gilts and surgically or immunologically castrated barrows of 92 to $125 \mathrm{~kg}$. Immunologically castrated males have the best performance responses to the ractopamine, but with losses in carcass yield, loin characteristics and backfat thickness of the belly.

\section{References}

AALHUS, J.L.; SCHAEFERA, A.L.; MURRAY A.C. et al. The effect of ractopamine on myofibre distribution and morphology and their relation to meat quality in swine. Meat Science, v.31, n.4, p.97-409, 1992.

ALMEIDA, E.C.; FIALHO, E.T.; RODRIGUES, P.B. et al. Ractopamine and lysine levels on performance and carcass characteristics of finishing pigs. Revista Brasileira de Zootecnia, v.39, n.9, p.1961-1968, 2010.

AMARAL, N.O.; FIALHO, E.T.; CANTARELLI, V.S. et al. Ractopamine hydrochloride in formulated rations for barrows or gilts from 94 to $130 \mathrm{~kg}$. Revista Brasileira de Zootecnia, v.38, n.8, p.1494-1501, 2009.

ARMSTRONG, T.A.; IVERS, D.J.; WAGNER, J.R. et al. The effect of dietary ractopamine concentration and duration of feeding on growth performance, carcass characteristics, and meat quality of finishing pigs. Journal of Animal Science, v.82, n.11, p.3245-3253, 2004.
ASSOCIAÇÃO BRASILEIRA DE CRIADORES DE SUÍNOS - ABCS. Método brasileiro de classificação de carcaças. Estrela: ABCS, 1973. 17p. (Publicação Técnica, 2).

CANTARELli, V.S.; FIALHO, E.T.; ALMEIDA, E.C. et al. Ractopamine for finishing barrows fed restricted or ad libitum diets: performance and nitrogen balance. Revista Brasileira de Zootecnia, v.38, n.12, p.2375-2382, 2009a.

CANTARELLI, V.S.; FIALHO, E.T.; ALMEIDA, E.C. et al. Características da carcaça e viabilidade econômica do uso de cloridrato de ractopamina para suínos em terminação com alimentação à vontade ou restrita. Ciência Rural, v.39, n.3, p.844-851, 2009b.

CANTARELLI, V.S.; ZANGERONIMO, M.G.; ALMEIDA, E.C. et al Qualidade de cortes de suínos recebendo ractopamina na ração em diferentes programas alimentares. Acta Scientiarum. Animal Science, v.30, n.2, p.165-171, 2008.

CARR, S.N.; RINCKER, P.J.; KILLEFER, J. et al. Effects of different cereal grains and ractopamina hydrochloride on performance, carcass characteristics, and fat quality in latefinishing pigs. Journal of Animal Science, v.83, n.1, p.223-230, 2005.

DUNSHEA, F.R.; COLANTONI, C.; HOWARD, K. et al. Vaccination of boars with a GnRH vaccine (Improvac ${ }^{\circledR}$ ) eliminates boar taint and increases growth performance. Journal of Animal Science, v.79, p.2524-2535, 2001.

DUNSHEA, F.R.; CADOGAN, D.J.; PARTRIDGE, G.G. et al. Dietary betaine and ractopamine combine to increase lean tissue deposition in ûnisher pigs, particularly gilts. Animal Production Science, v.49, p.65-70, 2009.

FERREIRA, M.S.S.; SOUSA, R.V.; SILVA, V.O. et al. Cloridrato de ractopamina em dietas para suínos em terminação. Acta Scientiarum. Animal Sciences, v.33, n., p.25-32, 2011.

GISPERT, M.; OLIVERA, M.A.; VELARDE, A. et al. Carcass and meat quality characteristics of immunocastraded male, surgically castrated male, entire male and female pigs. Meat Science, v.85, n.4, p.664-670, 2010 .

GUIDONI, A.L. Melhoria de processos para a tipificação e valorização de carcaças suínas no Brasil. In: CONFERÊNCIA INTERNACIONAL VIRTUAL SOBRE QUALIDADE DE CARNE SUÍNA, 2000, Concórdia. Anais... Concórdia: Embrapa Suínos e Aves, 2000. p.1-14.

JAROS, P.; BÜRGIA, E.; STÄRK, K.D.C. et al. Effect of active immunization against GnRH on androstenone concentration, growth performance and carcass quality in intact male pigs. Livestock Production Science, v.92, n.1, p.31-38, 2005.

JI, F.; HURLEY, W.L.; KIM, S.W. Characterization of mammary gland development in pregnant gilts. Journal of Animal Science, v.84, n.3, p.579-587, 2006.

MARINHO, P.C.; FONTES, D.O.; SILVA, F.C.O. et al. Efeito da ractopamina e de métodos de formulação de rações sobre o desempenho e as características de carcaça de suínos machos castrados em terminação. Revista Brasileira de Zootecnia, v.36, n.4, p.1061-1068, 2007a.

MARINHO, P.C.; FONTES, D.O.; SILVA, F.C.O. et al. Efeito dos níveis de lisina digestível e da ractopamina sobre o desempenho e as características de carcaça de suínos machos castrados em terminação. Revista Brasileira de Zootecnia, v.36, n.6, p.1791-1798, 2007b

MITCHELL, A.D.; SOLOMON, M.B.; STEELE, N.C. Response of low and high protein select lines of pigs to the feeding of the beta-adrenergic agonist ractopamine (phenethanolamine) Journal of Animal Science, v.68, n.10, p.3226-3232, 1990

MORAES, E.; KIEFER, C.; SILVA, I. S. Ractopamina em dietas para suínos machos imunocastrados, castrados e fêmeas. Ciência Rural, v.40, n.2, p.409-414, 2010.

PENA, S.M.; LOPES, D.C.; ROSTAGNO, H.S. et al. Relações metionina mais cistina digestível:lisina digestível em dietas suplementadas com ractopamina para suínos em terminação. Revista Brasileira de Zootecnia, v.37, n.11, p.1978-1983, 2008. 
RENTFROWA, G.; SAUBERB, T.E.; ALLEE, G.L. et al. The influence of diets containing either conventional corn, conventional corn with choice white grease, high oil corn, or high oil high oleic corn on belly/bacon quality. Meat Science, v.64, n.4, p.459-466, 2003.

RIKARD-BELL, C.; CURTIS, M.A.; VAN BARNEVELD, R.J. et al. Ractopamine hydrochloride improves growth performance and carcass composition in immunocastrates boars, intact bors and gilts. Journal of Animal Science, v.87, n.11, p.3536-3543, 2009.

ROSTAGnO, H.S.; ALBINO, L.F.T.; DONZELE, J.L. et al. Tabelas brasileiras para aves e suínos: composição de alimentos e exigências nutricionais. 2.ed. Viçosa, MG: UFV, 2005. 186p.
SCHINCKEL, A.P.; HERR, C.T.; RICHERT, B.T. et al. Ractopamine treatment biases in the prediction of pork carcass composition. Journal of Animal Science, v.81, n.1, p.16-28, 2003.

SEE, M.T.; ARMSTRONG, T.A.; WELDON, W.C. Effect of a ractopamine feeding program on growth performance and carcass composition in finishing pigs. Journal of Animal Science, v.82, n.8, p.2474-2480, 2004.

UTTARO, B.E.; BALL, R.O.; DICK, P. et al. Effect of ractopamine and sex on growth, carcass characteristics, processing yield, and meat quality characteristics of crossbred swine. Journal of Animal Science, v.71, n.9, p.2439-2449, 1993.

XUE, J.L.; DIAL, G.D.; PETTIGREW, J.E. et al. Performance, carcass, and meat quality advantages of boars over barrow: a literature review. Swine Health and Production, v.5, p.21-28, 1997. 